\title{
The concept of participatory market orientation: An organisation-wide approach to enhancing brand equity
}

Received (in revised form): 22nd August, 2007

\section{NICHOLAS IND}

is a partner in Equilibrium Consulting. He is the author of a number of articles and papers and eight books including The Corporate Image, The Corporate Brand, Living the Brand and Branding Governance (with Rune Bjerke). He is also the editor of Beyond Branding.

\section{RUNE BJERKE}

is an Associate Professor at Oslo School of Management. Previously, he taught at BI Norwegian School of Management. He holds a PhD from the University of Otago in New Zealand. He is the co-author of Branding Governance.

\section{Keywords participation, marked orientation, brand elements, brand equity}

Nicholas Ind Equilibrium Consulting Box 5822 Majorstuen Oslo 0308, Norway Tel: +479825 7724 E-mail:nind@ equilibriumconsulting.com

\section{Abstract}

While much marketing literature sees delivering customer experience as the role of the marketer, we argue that this is an organisation-wide responsibility. The organisation-wide approach is based on the premise that the brand-building capability of the organisation is determined by the combination of marketing, human resources, organisational culture, leadership and evaluation. It is our contention that the role of marketing should be concerned with connecting these elements to optimise brand equity (eg awareness, perceived quality, associations, loyalty). In this paper, we suggest a participative model for an organisation-wide approach where the role of the marketer is Janus-like in that he/she must face both outwards to connect with customers and other stakeholders and inwards to build coalitions inside the organisation to deliver a clear and consistent customer experience.

Journal of Brand Management (2007) 15, 135-145. doi:10.1057/palgrave.bm.2550122; published online 9 October 2007

\section{INTRODUCTION}

Much traditional marketing literature has a product and marketing communications-led approach to the idea of creating customer experience. Yet in most Western economies, it is services that predominate and consequently it is the other elements of customer-organisation interaction that are dominant in the formation of brand image. ${ }^{1}$ It is employees and their ability to build relationships with customers that determine value. ${ }^{2}$ The outside-in, insideout approach to brand building suggests the importance of aligning employees with the brand and in uncovering the meaning of the brand through participation. ${ }^{3}$ This shows the value of customer- facing employees in particular, but it is the collective effort of the organisation that is important, for as Chenet et al. ${ }^{4}$ suggest service delivery is a combination of culture, leadership, commitment, systems, tools and technology. It also indicates the value of entrainment ${ }^{5}$ - where the organisation is focused on enhancing customer experience not via abstracted thinking, but through a union of interest based on a dynamic relationship. ${ }^{6}$ This thinking extends the role of marketing by suggesting that its role should be not only to sense movement in the environment but also to shape the organisational response by connecting with other business functions and departments. One of the strands 
within marketing thinking that has tried to deal with the problem of marketing's overtly external emphasis is the concept of 'market orientation'.

\section{MARKET ORIENTATION}

The idea of market orientation is that organisations should focus on the interaction with customers and then look inward to explore how that customer knowledge can be used to build organisation-wide responses. Kohli and Jaworski ${ }^{7}$ saw the concept as referring to 'the organisationwide generation of market intelligence, dissemination of the intelligence across departments, and organisation-wide responsiveness to it'. Narver and Slater ${ }^{8}$ featured some similar elements, seeing market orientation as (1) customer orientation; (2) competitor orientation, and (3) interfunctional coordination. Narver and Slater's emphasis is, however, on market orientation as organisational culture, which they argue drives behaviour. This means that market orientation can only exist if there is a culture that is oriented towards customers. We should, however, remember that while culture drives behaviour, behaviour also drives culture. ${ }^{9}$ If we see culture as static we might come to the view that in a noncustomer-oriented culture, people cannot consistently be market oriented. Yet we would argue that culture is dynamic. Leaders cannot simply tell people to be more customer oriented and expect a transformation to occur, but they can lead by example and committed groups of individuals can change the organisational way of doing things by focusing on the delivery of customer value. This can lead to cultural change and enhanced market orientation. Jaworski and Kohli ${ }^{10}$ endorse the importance of leadership in their analysis of the antecedents of market orientation because of leaders' ability to stimulate an external focus 'through continual reminders to employees that it is critical for them to be sensitive and responsive to market developments'.

Gainer and Padanyi ${ }^{11}$ argue that researchers see market orientation as a cultural construct or a behavioural construct (separate or connected/correlated), or even a hybrid incorporating both cultural and behavioural aspects. Their study of nonprofit organisations showed that a positive relationship between marketoriented behaviours and organisational performance is mediated by market orientation. Further, Kee-hung and Cheng ${ }^{12}$ used data from 304 organisations, which had operational quality management systems, to investigate the relationship between quality orientation, market orientation and organisational performance. The study (based on both qualitative and quantitative data) revealed that quality orientation and market orientation are complementary and they authenticate the view that quality management and marketing reinforce each other in strengthening organisational performance. Lastly, Matsunoa et al. ${ }^{13}$ compare three different scales (the scales of Kohli and Jaworski, Narver and Slater and EMO ${ }^{14}$ _extended market orientation). Their conclusion: the Narver and Slater scale was found to be superior to the others in terms of predictive validity, but based on scale reliability, limited unidimensionality and construct domain no single scale examined here was found satisfactory.

\section{APPLYING MARKET-ORIENTED THINKING}

Market orientation stresses the importance of connecting the organisation together to deliver value to customers. It seeks to overcome the problem of 
siloisation that is prevalent in organisations and supports the concept of an organisation-wide approach. Researchers may debate whether it is a cultural or a behavioural construct, but our view is that these two ideas are interlinked. We see market orientation as a way of facing the worldin that sense it is a cultural construct. Culture is, however, about the way of doing things. It determines and is determined by behaviours. Yet, the real challenge is that organisations struggle with market orientation. Partly this is to do with the difficulty of changing culture in a managed way and partly to do with the problem of organisational fragmentation. Yet there seem to be other factors at work. Jaworski and Kohli's 1993 paper addressed three specific questions: (1) Why are some organisations more market oriented than others? (2) What effect does a market orientation have on employees and business performance? (3) Does the linkage between a market orientation and business performance depend on the environmental context? Based on two national samples the researchers argue that market orientation is related to top management emphasis, the risk aversion of top managers, interdepartmental conflict and connectedness, centralisation and reward system orientation. Moreover, a market orientation is related to overall business performance (but not market share), employees' organisational commitment and esprit de corps. And even more important, the connection between market orientation and performance appears to be consistent across environmental contexts that suffer from varying degrees of market turbulence, competitive intensity and technological change. We might conclude from this that there are no environmental reasons to prevent market orientation and plenty of benefits. This is supported by other research:
- Slater and Narver ${ }^{15}$ showed that the benefits of a market orientation are long term even though environmental conditions are often transient. Becoming market oriented is costeffective in the long term in spite of any possible short-term moderating effects of the environment. 'A market orientation is a particular form of business culture', and 'becoming and remaining market oriented are essential to the continuous creation of superior value' (Slater and Narver ${ }^{15}$, p. 53).

- Siguaw, Simpson and Baker ${ }^{16}$ discovered that a supplier's market-oriented behaviour directly or indirectly affects all the channel relationships examined from the distributor's perspective. In particular, the distributor's market orientation, trust, cooperative norms, commitment and satisfaction have an impact on financial performance.

- Hampton and Hampton ${ }^{17}$ found that professionalism and rewards were positively correlated with market orientation. Further, the study revealed market orientation was strongly and positively related to job satisfaction.

In our judgment, market orientation suffers from three limitations: (1) Researchers, while connecting market orientation to business performance, have not explicitly linked it to brand-building capability. (2) The measurement systems, as observed, have not been sufficiently deep. (3) Insufficient attention has been paid to the reality of how to engage the organisation to become market orientated. In particular, the whole area of implementation has been underplayed. A market-oriented culture is not only about inter-functional coordination (Slater and Narver 1994), dissemination (Kohli and Jaworski 1990) or the type of 
organisational antecedents (factors) that enhance or impede the implementation of the business philosophy. Rather market orientation is a consequence (although it in turn reinforces) of a supportive organisational culture, HR drivers and leadership. To develop this line of thinking, we have developed the concept of participatory market orientation: a fusion of internal ${ }^{18}$ and external market orientations with an emphasis on realising the potential of market orientation.

\section{PARTICIPATORY MARKET ORIENTATION}

Here we suggest a development of market orientation: participatory market orientation (PMO). A participatory marketoriented philosophy aims to build brand capability and brand equity by involving employees, customers and other stakeholders in the development of the brand. This suggests that the role of marketing as an organisational driving force is to help the organisation become participatory, such that all investments in external and internal marketing activities should encourage participation and strengthen the brand.

This indicates that PMO is an orientation that adheres to the idea of entrainment. This belief in the value of participation steers the way in which investments are made in both internal and marketing activities and recognises their connectivity. It suggests as a principle that, rather than an over-reliance on traditional marketing communications to build a brand, funds are allocated to become entrained with customers and to integrate a relevant organisational response encompassing communications and actions. This goes beyond the ideas of brand community $^{19}$ to demonstrate how organisations can build networks of genuine interest with customers. An example of this participatory process at work are the Grathak Katha (consumer's voice) events held by the Bangladeshi mobile operator GrameenPhone. GrameenPhone is the leading mobile telecom company in Bangladesh with a 62 per cent share of the market and $8.5 \mathrm{~m}$ customers (September 2006). This is a high growth market, but it is also extremely poor: the average GDP per head is $\$ 421$ (US) and GrameenPhone's business model is designed to work with customers whose average spend on mobile telephony is $\$ 2$ per month. To better understand its customers and develop innovative ways of selling its services, the company conducts regular market research studies and particularly the delivery of customer service. In addition to this research, GrameenPhone has initiated a process for removing the distance between the company and its customers. This participative approach involves regular meetings with customers in an environment that is both social and businesslike. The idea is to obtain direct interaction with customers both as a way of enhancing the reputation of the brand and as a means of learning about and learning with customers. At the events, GrameenPhone matches the attendees one to one with employees so that there is the opportunity for personal dialogue. On these occasions, research is conducted and results are presented, new products are discussed and customers provide ideas on new opportunities. The idea is to mix the formal and the informal and such has been the momentum behind the process that music performances at the events are by groups that combine employees and customers playing together. GrameenPhone has discovered that the quality of the feedback is high and the comments are genuine. Customers are not concerned with trying to either attack or please 
GrameenPhone, they just try to offer input and to relate their experiences. In one year the company conducted more than 300 events with over 200,000 participants. The key to maintaining the interest in the process both within GrameenPhone and externally with customers is the rapid processing of information, the actions taken as a result of input and the feedback provided. Marketing Director Rubaba Dowla Matin argues that the success is due to the organisational capability to validate, categorise and analyse the data and to involve the relevant teams in the organisation. It is these cross-functional customer management teams that play the vital role in determining the nature of the insight and in generating action and communication. This investment into deep and direct insight and the willingness to encourage organisation-wide participation have been the catalysts behind the success of the initiative and the company's burgeoning reputation as an innovator.

Another example is sportswear company Quiksilver, ${ }^{20}$ which achieves entrainment through several key mechanisms. It recruits people directly from the sports it serves (skateboarding, snowboarding, surfing), such that most people at Quiksilver, from the CEO and the key directors down, are board riders and employees are encouraged to take an active part in their sports. This helps to ensure that managers and employees are taking an active part in an ongoing dialogue with customers. Quiksilver employees do not have to resort to abstracted data to make informed decisions, they can work from current and direct experience. This is, however, not just one way. Quiksilver encourages interested people to contribute their ideas. The several hundred professional riders and an army of supported amateurs are an extension of the grassroots connection Quiksilver enjoyed in its early days when it was run as a hobbyist surf shorts business. Quiksilver knows that creativity has to meet with the approval of the enthusiast audience both to ensure it is a trend leader and to maintain its authenticity. Some innnovations are the direct result of input from riders, such as the development of surfing fiction books aimed at girls, and some ideas are the result of dialogue that provides inspiration for designers. Rapid feedback also tells the company when its products are not working as they should or its communications are not connecting. The important element of collaboration is the ability to listen. Quiksilver achieves this largely by treating the riders as insiders. The language of the company reflects this: riders are part of the organisational structure. They are welcomed at Quiksilver offices and they meet with employees at sporting events.

Within Quiksilver itself, the internal borders are played down and the importance of collaboration is emphasised. Groups are formed from across departments to explore ideas in largely informal, intuitive ways. The brand provides a template against which decisions are made, but there is also a strong belief in being openminded so that good ideas - whether they come from inside or outside-are not missed. Quiksilver's entrainment with its customers enables it to develop new ranges and communications without recourse to research.

The key requirements for entrainment are a sufficient degree of interest (from both employees and customers) and a receptivity to ideas from different sources both inside and outside the company. For example, many of Apple's heralded innovations (iPod, iTunes, multi-touch) have been adaptions and development of technologies generated from outside the organisation. Similarly Lego's development of its second-generation Mind- 
storms range was due to the unanticipated input of AFOL (Adult Fans of Lego) users, which initially the organisation ignored and then, having realised its potential, coopted into product design. Also, online organisations such as Amazon, e-Bay and Wikipedia, and the whole Open Source Movement thrive on an intensive sense of engagement, because they enable people to achieve a Maslowian sense of selfrealisation and the plaudits of their peers. These online brand builders have largely eschewed traditional forms of marketing communication. Instead their power has grown through a transparent approach, the encouragement of sharing and wordof-mouth engagement. ${ }^{21,22}$ Our judgment is that in future, the only real control will be in having an authentic, participative brand. That means bringing the customer inside the organisation and aligning the whole organisation to create relevant value. In software development, the writer Eric Raymond calls this the Bazaar model and contrasts it with the Cathedral model where the source code is a carefully guarded secret. ${ }^{23}$ In the essay 'The Cathedral and the Bazaar', Raymond suggests that the Bazaar model is a more effective way of testing software code than the Cathedral model, which has to guess customer reactions. In reviewing the Bazaar and Cathedral model, Andreas Mack writes: 'Looking at brands we discover cathedrals all around us. Polished up brands launching into stardom or disappearing into failure. Brands secretly pre-tested and pumped up with meaning, structure and visuals, creating identities to last a lifetime... A bazaar approach to branding lets consumers, retailers, press and public take a peek behind the scenes and have a say when decisions are made...Smart brands will welcome the consumer's role as a natural partner in a collective process of product and brand development'. ${ }^{24}$
Marketing's role then shifts subtlety with a PMO. Marketing becomes concerned with helping to create an organisation-wide commitment to customers and a supportive culture, style of leadership, governance and human resources policies. Partly marketing must have an internal market orientation to achieve this organisation-wide perspective and partly it must be a key element in building bonds with customers and sharing knowledge about them inside the organisation: externally sense-making and internally sensesharing. This internal/external approach builds the brand. The value of this twin perspective is endorsed by a study of Sweden's 500 largest companies ${ }^{25}$ that shows organisations with the highest brand orientation index (BOI), where branding is the hub of operations are characterised by an ability to combine both an internal and external focus. Interestingly, the profile of high brand orientation companies is found in roughly the same frequency among business-to-business and business-to-consumer companies $(50 / 50)$ and goods to services $(57 / 43)$. This study reinforces the link between brand orientation and profitability suggested in the PMO value chain, by demonstrating the correlation between the two with the group of leaders in terms of orientation showing operating profits almost double the lowest brand orientation group: 'the most important outcome of this study is that we have been able to establish a clear link between brand orientation and profitability: the more brandoriented a company is, the more profitable it is'.

\section{PMO AND BRAND EQUITY}

In recognising the importance of human capital and internal market orientation, it must be remembered that the value of this 
is in building brand equity and delivering customer experience. Brand equity and the brand elements constituting a brand are much discussed in marketing literature. Kapferer's ${ }^{26}$ brand identity model proposes brand components or dimensions (brand elements) such as physique (a product's objective and tangible basis), personality (the character), culture (set of values feeding the brand's inspiration), relationship (love and friend), reflection ('the customer should be reflected as she/he wishes to be seen as a result of using the brand') and self-image (one's own internal mirror stimulating an inner relationship with ourselves). Aaker and Joachimsthaler ${ }^{27}$ distinguish between product elements (scope, attributes, uses, quality/value, functional benefits) and brand elements (brand personality, symbols, brand/customer relationship, self-expressive benefits, emotional benefits, user imagery, country of origin and organisational associations). De Chernatony and Dall'Olmo Riley ${ }^{28}$ suggest a tangible - intangible spectrum ranging from concrete, physical characteristics (tangible) to those of a more abstract/ immaterial (intangible) nature. Keller ${ }^{29}$ argues that the intangible elements do not constitute brand elements as he believes a brand element is 'trademarkable' visual or verbal information that identifies and differentiates a product or service - the most common ones being names, logos, symbols, characters, slogans and packaging. Most viewpoints on brand equity have an external orientation to the building of the brand and imply that the way to increase brand equity is through investments in marketing efforts. In contrast, de Chernatony and McDonald ${ }^{30}$ see equity as broader by including organisational dimensions as input variables in increasing brand equity. This underlines the importance of the brand's vision, mission, organisational culture and values. ${ }^{31}$ It suggests that most of the value creation of the brand equity takes place within the framework of the organisation and that customers' confidence in the brand determines the financial value of the brand.

The essential role of brand elements is to contribute to the formation of consumer confidence. But brand elements by themselves do not create the condition of confidence. Confidence and trust comes into being through experience, ${ }^{32}$ which again suggests the vital role played in the delivery of customer experience by brand aligned employees. For this reason, we differentiate between brand elements and the organisational elements that deliver the product and service. Vision, mission, values and cultural heritage are not brand elements but are rather driving forces that guide the strategic direction of the brand to enhance brand experience and thus brand equity.

\section{BECOMING PARTICIPATORY}

Achieving a balance ${ }^{33}$ between the internal and external requires a PMO. This is something that the organisational culture has to encourage and that leadership must demonstrate by its communications and actions - something the BOI study endorses with its discovery that in the most brand-oriented companies, the executive management group is very active in brand-related activity. Market orientation suggests as its first principle that there is an organisation-wide responsibility to gather market intelligence. Partly this is about the ability to gather and use market research effectively, but it is also about the principle of entrainment: of getting genuinely close to customers, so that the acquisition of knowledge is direct and unmediated. This is what Quiksilver does through its free-flow connectivity and GrameenPhone achieves with their 
Grathak Katha. These are markets of exchange, where organisations seek to listen to and connect with customers. The challenge here is not to organise the mechanisms of exchange but to approach the customer with an open mind and a willingness to accept ambiguity and uncertainty: 'any creative thinker who ventures into new territory risks chaos and fragmentation'. ${ }^{34}$

If the organisation has permeable boundaries, so that it can easily absorb knowledge, the next stage in PMO is the ability to connect people internally in developing a response. This requires a sense of organisational unity and a conducive communication climate. Referring to how organisations communicate internally, Van Riel ${ }^{35}$ writes that communications research 'stresses the importance of "soft" aspects in communication like openness, honesty and participation in decision-making, resulting in the necessity for managers to pay serious attention to communication climate, specifically their own role in improving the climate'. Making the climate effective will always be easier to achieve if there is a strong sense of unity built around the identification with and internalisation of the organisational vision and values and a connectivity with customers. If people have a common aim and a shared sense of accountability, it is easier to react to events. ${ }^{36}$ This is not to suggest that individuals simply operate on automatic based on the vision and values - rather it suggests that the implications of the vision and values are understood and help in decision-making both as a point of inspiration and as a guide to behaviour. In fact, the forward momentum in the process of discussion and debate needs to be contained within the vision and values themselves as this encourages the discovery of meaning through discourse. The vision and values should stimulate debate; the organisation needs the 'dirt' that fuels creativity. ${ }^{37}$

This importance of a shared vision and values might suggest the denial of diversity. Yet we argue in favour of diversity and adaptability provided there is a common understanding of the vision and values. ${ }^{38}$ There needs to be an organisational acceptance of tension, a willingness to avoid too much control and an embracing of diversity that creates the opportunity for innovation within the framework set by the vision and values: 'we are starting to think of heterogeneity as something valuable, not as an obstacle to unification'. ${ }^{39}$ When there is a lack of connection with the vision and values or an attempt to force homogeneity, siloisation is more likely as people turn inwards to their own business unit agendas and away from the organisational whole. This fragmentation prevents the sharing of knowledge and inhibits the development of a unified approach to events.

Although homogeneity may appear desirable it creates contradictions. If the organisation tries to prescribe employee behaviour in line with the vision and values, it is reducing the opportunity to discover the meaning of those same vision and values. It is trying to make something that is inherently dynamic, static and unchanging. It is far more productive to allow the meaning of the vision and values to develop in response to events. This suggests that alongside the planned organisational systems, there has to be sufficient allowance for adaptation as the culture, identity and image of the organisation change. The element that separates the participatory approach is the idea of personal and direct engagement by managers and employees, who understand and are able to explore the framework of the brand. It suggests an ongoing dialogue with customers and 
with colleagues and relationships built on trust and openness.

\section{CONCLUSION}

PMO builds on the role of a free market in which most participants wish to optimise the process of exchange. In other words, parties involved in exchanges want to be as efficient and effective as possible: the organisation wants to acquire insight and deliver relevant products and services and external audiences want to acquire resources and the accompanying rights of ownership or usage. In a market-oriented organisation, the exchange is hindered potentially by several factors: (a) the ability to collect meaningful and usable insights; ${ }^{40}$ (b) the ability to share knowledge within the organisation; ${ }^{41}$ (c) the ability to unify organisational actions to deliver resources. These challenges are not the result of a flawed concept, but more the lack of attention given to the operationalisation of the concept. This has been the motivation behind the development of the concept of PMO. This concept suggests a unity based on a closeness between employees and customers and between employees. It is only when employees are entrained with customers that they are able to acquire deep insight into behaviour and it is only when employees and managers are able and willing to work across organisational boundaries that value can be delivered consistently to the customer. This indicates the importance of such aspects as organisation culture and leadership. It is only when the organisation is able to communicate effectively across boundaries that closeness can be achieved. This relates to Ling's idea of internal market orientation and the importance of fusing the organisation together. One important element in this is bringing marketing and human resources closer. This ought to be something that is considered in the planning of management education and also in the structuring of organisations. ${ }^{42}$

The whole process of market orientation can be more or less participatory. The lower the involvement of customers in the process, the more likely it is that the organisation will be seller centric. ${ }^{43}$ The lower the involvement of employees, the more likely it is that the organisation will not meet customer expectations. Therefore, the aim should be for high levels of participation to become entrained with customers. This suggests that many people in the organisation should be involved with the marketing process and consequently with brand building. As an area of functionality, people in marketing should be responsible for and focus on the relationship with the customer: researching attitudes and behaviour, sharing knowledge internally, developing and executing marketing communication plans internally and externally and stimulating collective thinking and actions. Within this range of functions, we would stress the need for genuine insight into customers, the need to share knowledge internally, and most importantly, the ability to galvanise the organisation into action to deliver the brand as a seamless experience.

\section{References and Notes}

(1) Thomson, K. and Hecker, L.A. (2000) 'The business value of buy-in: How staff understanding and commitment impact on brand and business performance', in Varey, R. and Lewis, B. (eds) 'Internal Marketing: Directions for Management', Routledge, London.

(2) Edvinsson, L. and Malone, M. (1998) 'Intellectual Capital', Piatkus, London.

(3) Ind, N. and Bjerke, R. (2007) 'Branding Governance: A Participatory Approach to the Brand Building Process', Wiley and Sons, Chichester.

(4) Chenet, P., Tynan, C. and Money, M. (2000) 'The service performance gap: Testing the redeveloped causal model', European Journal of Marketing, Vol. 34, No. 3/4, pp. 472-495. 
(5) Entrainment is the process whereby two connected oscillating systems, having similar periods, fall into synchrony. The system with the greater frequency slows down, and the other accelerates. Christian Huygens, a notable physicist, coined the term entrainment after he noticed, in 1666, that two pendulum clocks had moved into the same swinging rhythm, and subsequent experiments duplicated this process. The accepted explanation for this is that small amounts of energy are transferred between the two systems when they are out of phase in such a way as to produce negative feedback. As they become more in phase, the amounts of energy gradually reduce to zero. In the realm of physics, entrainment appears to be related to resonance (from www.wikipedia.org).

(6) Antorini, Y. M. and Andersen, K. (2005) 'A communal approach to corporate branding', in Majken, S., Antorini, J.M. and Csaba, F. (eds) 'Corporate Branding: Purpose/People/Process', Copenhagen Business School Press, Frederiksberg, Denmark.

(7) Kohli, A. K. and Jaworski, B. J. (1990) 'Market orientation: The construct, research propositions, and managerial implications', Journal of Marketing, Vol. 54, pp. 1-18.

(8) Narver, J. C and Slater, S. F. (1990) 'The effect of a market orientation on business profitability', Journal of Marketing, Vol. 54, No. 4, pp. 20-35.

(9) Ind, N. and Bjerke, R. (2007) 'Branding Governance: A Participatory Approach to the Brand Building Process', Wiley and Sons, Chichester.

(10) Jaworski, B. and Kohli, A. (1993) 'Market orientation: Antecedents and consequences', Journal of Marketing, Vol. 57, pp. 53-70.

(11) Gainer, B. and Padanyi, P. (2005) 'The relationship between market-oriented activities and market-oriented culture: Implications for the development of market orientation in non-profit service organizations', Journal of Business Research, Vol. 58, No. 6, pp. 854-862.

(12) Kee-hung, L. and Cheng, E. (2005) 'Effects of quality management and marketing on organizational performance', Journal of Business Research, Vol. 58, No. 4, pp. 446-456.

(13) Matsuno, K., Mentzer, J. and Rentz, J. (2005) 'A conceptual and empirical comparison of three market orientation scales', Journal of Business Research, Vol. 58, pp. 1-8.

(14) Matsunoa, Mentzer, and Rentz's extended market orientation model accommodates differences in the conceptualisations of Narver and Slater and Kohli and Jaworski by distinguishing market orientation as organisational culture (an antecdent) from market orientation as a set of behaviours (firm's conduct).

(15) Slater, S. F. and Narver, J. C. (1994) 'Does competitive environment moderate the market orientation-performance relationship?' Journal of Marketing, Vol. 58, pp. 46-55.

(16) Siguaw J, A. and Diamantopoulos, A. (1995) 'Measuring market orientation: Some evidence on Narver and Slater's three-component scale', Journal of Strategic Marketing, Vol. 3, No. 2, pp. $77-89$.

(17) Hampton, G. M. and Hampton, D. L (2004) 'Relationship of professionalism, rewards, market orientation and job satisfaction among medical professionals: The case of certified NurseMidwives', Journal of Business Research, Vol. 57, No. 9, pp. 1042-1053.

(18) Lings, I. N. (2004) 'Internal market orientation: Construct and consequences', Journal of Business Research, Vol. 57, No. 4, p. 405.

(19) Muniz Jr., A. M and O'Guinn, T. C. (2001) 'Brand community', Journal of Consumer Research, Vol. 27, No. 4, pp. 412-432.

(20) Ind, N. and Watt, C. (2004) 'Inspiration: Capturing the Creative Potential of Your Organisation', Palgrave, Basingstoke, Hants.

(21) Lévy, P. (1997) Bononno, R. (trans) 'Collective Intelligence: Mankind's Emerging World in Cyberspace', Perseus Books, Cambridge, Mass.

(22) Morner, M. (2003) 'The emergence of opensource software projects: How to stabilise selforganizing process in emergent systems', in Bakken, T. and Hernes, T. (eds) 'Autopoietic Organization Theory', Abstrakt Forlag, Oslo, pp. 259-271.

(23) Raymond, E. S. (1999) 'The Cathedral and the Bazaar', first presented in 1997, O'Reilly.

(24) Mack, A. (2004) at http://www.nicholasind. com/newsletter/001.html.

(25) Gromark, J. and Melin, F. (2005) 'Brand Orientation Index-A Research Project on Brand Orientation and Profitability in Sweden's 500 Largest Companies', Label, Göteborg.

(26) Kapferer, J. -N. (1997) 'Strategic Brand Management: Creating and Sustaining Brand Equity Long Term', 2nd edn, Kogan Page, London.

(27) Aaker, D. A. and Joachimsthaler, E. (2000) 'Brand Leadership', The Free Press, New York.

(28) de Chernatony, L. and Dall'Olmo Riley, F. (1998) 'Defining a "Brand": Beyond the literature with experts' interpretations', Journal of Marketing Management, Vol. 14, pp. 417-443.

(29) Keller, K.L. (2005) 'Branding shortcuts', Marketing Management, Vol. 14, No. 5, pp. 18-23.

(30) de Chernatony, L. and McDonald, M. (1998) 'Creating Powerful Brands: in Consumer, Service and Industrial Markets', 2nd edn, Butterworth Heinemann, Oxford.

(31) de Chernatony, L. and Dall'Olmo Riley, F. (1998) 'Modelling the components of the brand', European Journal of Marketing, Vol. 32, No. 11/12, pp. 1074-1090. 
(32) Williams, B. (2002) 'Truth and Truthfulness', Princeton, Princeton University Press.

(33) This is what the writer Chris Macrae refers to as transparent trust flow mapping so that the creation of value for one stakeholder group does not destroy value for another (detecting win-lose conflicts and changing to win-win). 'Brand, Dynamic Valuation and Transparent Governance' in Ind, Nicholas (ed.) 'Beyond Branding: How the New Values of Transparency and Integrity are Changing The World Of Brands', Kogan Page, London, 2003, pp. 87-103. Similarly, Greenley, G. E., Hooley, G. J. and Rudd J.M. (2005) question "whether a market orientation approach focuses too heavily on customers at the expense of other stakeholders? Managers also need to address the interests of other stakeholders when making marketing decisions. This gives an orientation to each stakeholder group, which exist simultaneously, giving a multiple stakeholder orientation profile (MSOP)'.

(34) Ehrenzweig, A. (2000) 'The Hidden Order of Art', Phoenix Press, London, p. 147.

(35) Van Riel, C. (1999) 'Ten years of research 19881998 of the Corporate communication centre, Erasmus University, Rotterdam', Special Issue on
Communication Research in Belgium and the Netherlands.

(36) Ind, N. (2001) 'Living the Brand: How To Transform Every Member of Your Organization into a Brand Champion', Kogan Page, London.

(37) Douglas, M. (2004) 'Purity and Danger', (Routledge and Kegan Paul, 1966). Routledge Classics, London.

(38) Denison, D. (2000) 'Organizational culture: Can it be a key lever for driving organizational change?', in Cooper, S. and Cartwright, C. (eds) 'The Handbook of Organizational Culture', John Wiley and Sons, London.

(39) Delanda, M. (2003) 'A Thousand Years of Nonlinear History', Swerve, New York, p. 274.

(40) Ronell, A. (2005) 'The Test Drive', University of Illinois Press, Urbana and Chicago.

(41) Kotler, P. (1984) 'Marketing Management: Analysis, Planning and Control', 5th edn, PrenticeHall, New York.

(42) In the Norwegian technology and industry conglomerate, Aker this union is achieved by having a Director in charge of both communications and human resources.

(43) Mitchell, A. (2000) 'Right Side Up: Building Brands in the Age of the Organized Consumer', Harper Collins Business, New York. 